\title{
Liquidity Risk Financial Disclosure: The Case Of Large European Financial Groups
}

Abderrahim Boussanni, Université de Sherbrooke, Canada Jean Desrochers, Université de Sherbrooke, Canada

Jacques Préfontaine, Université de Sherbrooke, Canada

\begin{abstract}
This paper examines the informational content and the usefulness of financial groups' liquidity risk public financial disclosure. This theme is of interest since the factors that influence the level of liquidity risk are complex, and they strongly interact with other originating factors from related financial risks. These characteristics have made it more difficult for financial services industry regulators and private sector ERM experts to recommend a practical and well defined framework for the management and subsequent public disclosure of liquidity risk financial information. The results of the study are based on an in-depth content analysis of the Annual reports (2004) published by twenty-one of Western Europe's largest financial groups using the liquidity risk management factors proposed by the Basel Committee on Banking Supervision and its Joint Forum (2003, 2006). The results of the study revealed a disparity between commercial banks from the same or different European countries as to the level and extent of liquidity risk public financial disclosure. The same was also found for the description of the risk management structures and the accompanying explanatory comments on liquidity risk management practices. In addition, the study documented the overall scarcity of quantitative data which supports qualitative discussions on liquidity risk management. There were also areas of more complete financial disclosure that apply to factors explaining the origins of cash flows, and the explanations and discussion about foreign exchange risk management.
\end{abstract}

Keywords: Enterprise risk management, financial disclosure, liquidity risk, BIS, FRB, SEC.

\section{INTRODUCTION}

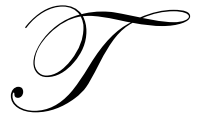

his paper examines the informational content and the usefulness of financial groups' liquidity risk public financial disclosure. This theme is of interest since the factors that influence the level of liquidity risk are complex, and they strongly interact with other originating factors from related financial risks. These characteristics have made it more difficult for financial services industry regulators and private sector ERM experts to recommend a practical and well defined framework for the management and subsequent public disclosure of liquidity risk financial information. Lopez (2003), and more recently, Kwan (2006) explained the ongoing international efforts to improve the regulation and supervision of financial institutions to reflect advances in financial risk management techniques. Their analysis supports the view that improved public disclosures regarding conditions, operations, performance and risk management information lead to increased transparency and should foster more effective market discipline.

The evolution of financial disclosure in the banking, insurance and securities sectors has been described in a study published by the Joint Forum (2004) of the Basel Committee on Banking Supervision (BCBS). The BCBS, the International Association of Insurance Supervisors (IAIS) and the International Organization of Securities Commissions (IOSCO) established, through the Joint Forum, a Working Group on enhanced disclosure. This paper will also examine the results of a recent review by the Joint Forum's working group (2006) of funding liquidity risk 
management practices at conglomerates engaged in banking, securities, and insurance activities. The results presented in this study are based on an in-depth content analysis of the 2004 annual reports published by twenty-one of Western Europe's largest financial groups using the liquidity risk management factors proposed over time by the BCBS and its Joint Forum (2003, 2004 and 2006).

The rest of the paper is structured as follows: Agency theory is presented in section two. Section two also defines and examines the key liquidity risk management factors. An important distinction is made between a financial group's funding liquidity risk and its market liquidity risk. The third section describes the research methods, the financial group sample data, and formulates hypotheses on the extent and quality of financial groups' qualitative and quantitative disclosures of liquidity risk management information. Section four presents and discusses the study's empirical results. Finally, the conclusions, limits of the study and suggestions for further research are drawn in the fifth section.

\section{IMPROVED LIQUIDITY RISK FINANCIAL DISCLOSURE}

Gardner et al. (2005) discuss how Agency Theory, a positive view of managerial decision making helps explain how risk management decisions are actually made by financial institution managers rather than prescribing how they should be made. In their view, Agency Theory implies that financial institutions' managers set financial risk management objectives and determine estimates of potential losses that could result from their business activities. While owners and their delegated monitors (regulators, credit rating agencies, financial analysts...) protect their interests by setting appropriate risk management constraints and financial disclosure standards and requirements.

Recently, several authors have examined if improved financial risk information disclosures lead to increased transparency and more effective market discipline. In his study of VaR disclosures, Jorion (2002) found that VaR numbers in quarterly and annual reports from 1995 to 2000, of eight publicly traded U.S. commercial banks provided reasonable predictions of the subsequent variability of their trading revenues.

Hirtle (2003) found that the market risk minimum capital adequacy requirement measure reported by commercial banks is informative of the level of market risk associated with the trading activities of U.S. commercial banks. In still another study, Liu, Ryan and Tan (2004) reported that the VaR measure also had an informational content about the systematic risk and the total risk encountered by U.S. commercial banks. Préfontaine et al. (2006a) recently presented comparable results on Canadian banks' VaR disclosures. In another area of financial risk management; that is, non-trading interest rate risk management, Lopez (2004) documents the usefulness of financial institutions' disclosures. The results of several empirical tests support the view that the disclosure of non-trading interest rate risk metrics like Earnings-at-Risk and Economic Value of Equity-at-Risk represents useful information to market participants. This last conclusion applies to U.S. banks according to Lopez (2004) and to large U.S. and Canadian commercial banks studied by Préfontaine et al. (2006b).

Some of the earlier work by the BCBS discussed the role of information in effective market discipline and effective supervision. It established that financial institution transparency would be enhanced by public disclosure and supervisory information that promote safety and soundness. The BCBS (2000) study outlined a set of sound practices for managing liquidity in banking organisations. This updated guidance was organised around a set of fourteen principles falling into the following eight key liquidity management areas: developing a structure for managing liquidity, measuring and monitoring net funding requirements, managing market access, contingency planning, foreign currency liquidity management, internal controls for liquidity risk management, role of public disclosure improving liquidity and role of supervisors.

During the same time period, the Working Group (Joint Forum) formulated and recommended disclosure practices regarding financial risks. The universe of financial intermediaries to which the recommendations were intended consists of banks, securities firms, insurance companies and hedge funds. The Working Group believed that these financial intermediaries, regulated and unregulated, should periodically disclose both qualitative and quantitative financial information, when material, in a way that in the firm's judgement most meaningfully expresses 
its exposures to financial risks. The Working Group (2001) specifically made the recommendations to disclose: "substantive qualitative discussion of funding liquidity risk that includes some quantitative information supporting the discussion." The Working Group also recommended that disclosures be made which cover two important aspects of liquidity management: funding liquidity risk and market liquidity risk.

More recently, the BCBS (2003) published a report providing an overview of the disclosure practices of a sample of internationally active banks. The survey focussed on the year 2001 annual reports of 54 banks headquartered in the Committee's member countries. The survey included 104 questions addressing quantitative and qualitative disclosures in twelve different categories. In general terms, the survey revealed that many banks have continued to expand the extent of their disclosures. Overall, in book year 2001, banks disclosed $63 \%$ of the items, 104 questions, included in the survey, up from 59\% in 2000 and $57 \%$ in 1999. In the main findings of its study, the BCBS (2003) noted: "The most noteworthy improvement is the increase in the disclosure of information on other risks (operational and legal risks, liquidity risk and interest rate risk in the banking book)". It added that this information has now become as commonly disclosed as the basic information on market risk or credit risk. It also reported that: "85\% of the banks disclosed quantitative and qualitative information and strategies for managing liquidity risk in their year 2001 annual reports, up from 78\% in 2000 and 63\% in 1999". We believe that the BCBS findings reported above on liquidity risk management financial disclosures can only be considered to be preliminary. This belief is based on the fact that only one out of a possible 104 questions in the three successive disclosure surveys, 1999-2000-2001, directly addressed the liquidity risk management category. Furthermore, the survey results in this case only represent the number of affirmative answers to the presence of "disclosed quantitative and qualitative information and strategies for managing liquidity risk". For instance, the number of affirmative answers to the single liquidity disclosure question was 46 (banks) out of a possible 54 banks in 2001; thus, a disclosure rate of $85 \%$.

To assess the extent to which its previous recommendations were adopted, the BCBS and its Joint Forum (2004) reviewed the 2002 annual reports of 66 financial institutions from 12 countries in the banking, insurance and securities sectors. In addition to surveying public disclosures, the Working Group held meetings with representatives from the investment community, credit rating agencies and financial firms in order to gain their views in the degree of adoption of its previous recommendations and ways to improve public disclosures. The Working Group found that disclosure related to funding liquidity risk is a very complex issue, due primarily to the difficulty of quantifying the level of the risk in a way that is meaningful for disclosure purposes as well as the firm's sensitivity that such disclosures must be carefully considered in order not to provide misleading and potentially damaging information. Of more importance to the focus of this study, was the fact that with few exceptions, most of the firms surveyed included a discussion of funding liquidity in their annual reports. However, the extent of quantitative information supporting the discussion is generally weak. Members of the Joint Forum stated that improvement in quantitative disclosures with regard to funding liquidity risk was clearly needed. Although they believed that the way to do this effectively remained a challenge. The Working Group also reviewed disclosure areas requiring further investigation and development from a conceptual point of view. The Working Group agreed that further work in three of these areas should be pursued: disclosures of risk concentrations, potential future exposure and funding liquidity risk. It felt that the goal should be to find a way for financial firms to disclose in a meaningful way information they already possess as part as their internal risk management processes. The last paper we review was presented by the BCBS and its Joint Forum (2006), it presented the results of a review of funding liquidity risk management practices ${ }^{1}$ at conglomerates engaged in banking, securities and insurance activities. The review focussed on 40 large, complex financial groups with operations spanning national borders, financial sectors and currencies. The majority of the financial institutions represented in the review were involved in at least two of the banking, securities, or insurance sectors. All observations were based on information and opinions provided by the firms through written responses to a survey, interviews and presentations to the Working Group. The review was designed to address five key questions:

\footnotetext{
1 "Funding liquidity risk is the risk that the firm will not be able to efficiently meet both expected and unexpected current and future cash flow and collateral needs without affecting either daily operations or the financial condition of the firm. It differs from market liquidity risk, which is the risk that a firm cannot easily offset or eliminate a position without significantly affecting the market price because of inadequate market depth or market disruption." As the Working Group observes, in many cases, the same factors may trigger both types of liquidity risk.
} 
- How large, complex banking, securities and insurance groups manage liquidity risks across jurisdictions, sectors, and subsidiary units, particularly in times of stress;

The impact of regulatory and supervisory approaches on liquidity risk management practices and structures;

The nature of the products and activities that give rise to significant demands for liquidity;

Assumptions that firms make regarding available sources of liquidity; and

The scale of liquidity shocks that firms are prepared to address.

The Working Group reviewed the extent to which financial groups integrate liquidity risk management across sectors. Firms in each of the three sectors, banking and insurance as well as securities, monitor and manage liquidity risk primarily through the use of risk limits, monitoring systems, and scenario analyses that are incorporated into contingency funding plans (CFPs). However, given differences in business lines and funding mix, liquidity risk management is mostly separated in financial groups that contain firms operating in multiple sectors.

Previous empirical work has demonstrated the importance and complexity of financial institutions' liquidity risk financial disclosure. There appears to be a wide consensus that further work in the area of managing and reporting liquidity risk should be pursued. In doing so, the two following aspects of liquidity risk have to be considered: funding liquidity risk and market liquidity risk. Further empirical work benefits from updated guidance organized around a set of principles falling into several liquidity management areas. Financial institutions' quarterly and annual reports represent important and low-cost sources of financial disclosure to all of their stakeholders. Liquidity risk financial information should embody substantive qualitative disclosures that include some quantitative information supplementing the discussion.

\section{EXAMINING THE EXTENT OF LIQUIDITY RISK FINANCIAL DISCLOSURE}

The objective of this paper is to examine the informational content and the usefulness of financial groups' liquidity risk public financial disclosure. The results of the analysis will be based on an in-depth content analysis of the annual reports (year 2004) published by twenty-one of Western Europe's largest financial groups using ten key liquidity risk management factors proposed by the BCBS and its Joint Forum (2003, 2006).

\section{The Results Of The Analysis Will Attempt To Answer The Following Four Questions:}

- Question 1: Does the extent of liquidity risk financial disclosure differ across the 21 large financial groups composing the study sample?

- $\quad$ Question 2: Does the extent of liquidity risk financial disclosure differ across the 10 key liquidity risk management factors used in the analysis?

- Question 3: Does the extent of liquidity risk financial disclosure differ across the 9 home countries of the 21 large financial groups composing the sample?

- Question 4: Does the extent of liquidity risk financial disclosure differ across the credit rating of each of the 21 large financial groups composing the study sample?

\section{Large Financial Group Sample Description}

The sample which is composed of twenty-one of Western Europe's largest financial groups was drawn from the Euromoney Magazine July 2005 financial groups classification. Table 1 in the text lists the financial groups by country of origin, and provides the value of each group's shareholders' equity, total assets as well as its Moody's long term bond credit rating. Nineteen of the twenty-one financial groups were also included in the 2001 disclosure survey by the BCBS (2003); moreover, thirteen of these were also included in the BCBS and its Joint Forum (2004) study of financial disclosure issues and analysis. 
Table 1

Sample Of Western European Financial Groups

\begin{tabular}{|c|c|c|c|c|}
\hline Country & $\begin{array}{c}\text { Financial } \\
\text { Group } \\
\end{array}$ & $\begin{array}{l}\text { Sh. Equity } \\
\text { (M \$ U.S.) }\end{array}$ & $\begin{array}{l}\text { Total Assets } \\
\text { (M \$ U.S.) }\end{array}$ & $\begin{array}{l}\text { Moody's } \\
\text { Cr. Rating }\end{array}$ \\
\hline U.K. & $\begin{array}{c}\text { HSBC Holdings } \\
\text { Royal Bank of Scot. } \\
\text { Barclays } \\
\text { HBOS } \\
\text { Lloyds TSB Gr. }\end{array}$ & $\begin{array}{l}99,817 \\
68,768 \\
47,098 \\
39,563 \\
20,370 \\
\end{array}$ & $\begin{array}{c}1,276,778 \\
1,124,108 \\
1,005,857 \\
853,255 \\
539,146 \\
\end{array}$ & $\begin{array}{l}\text { Aa2 } \\
\text { Aa1 } \\
\text { Aa1 } \\
\text { Aa2 } \\
\text { Aaa }\end{array}$ \\
\hline France & $\begin{array}{l}\text { Groupe Cr. Agr. } \\
\text { BNP Paribas } \\
\text { Soc. Générale } \\
\text { Gr. Caisse Ép. }\end{array}$ & $\begin{array}{l}67,621 \\
48,825 \\
31,400 \\
25,544 \\
\end{array}$ & $\begin{array}{c}1,245,213 \\
1,236,062 \\
820,126 \\
742,112 \\
\end{array}$ & $\begin{array}{l}\mathrm{Aa} 2 \\
\mathrm{Aa} 2 \\
\mathrm{Aa} 3 \\
\mathrm{Aa} 2\end{array}$ \\
\hline Spain & $\begin{array}{c}\text { Santander } \\
\text { Banco B.V.A. }\end{array}$ & $\begin{array}{l}65,187 \\
35,089 \\
\end{array}$ & $\begin{array}{l}785,073 \\
424,427 \\
\end{array}$ & $\begin{array}{l}\mathrm{Aa} 3 \\
\mathrm{Aa} 2\end{array}$ \\
\hline Germany & Deutsche Bank & 35,343 & $1,146,189$ & Aa3 \\
\hline Switzerland & $\begin{array}{c}\text { Cr. Suisse Gr. } \\
\text { UBS }\end{array}$ & $\begin{array}{l}37,521 \\
35,630\end{array}$ & $\begin{array}{c}962,952 \\
1,533,306\end{array}$ & $\begin{array}{l}\mathrm{Aa} 3 \\
\mathrm{Aa} 2\end{array}$ \\
\hline Netherlands & $\begin{array}{l}\text { Rabo Bank Ned. } \\
\text { ABN AMRO Gr. } \\
\text { ING Group }\end{array}$ & $\begin{array}{l}33,452 \\
27,834 \\
21,736 \\
\end{array}$ & $\begin{array}{l}648,211 \\
830,405 \\
841,117 \\
\end{array}$ & $\begin{array}{l}\text { Aaa } \\
\text { Aa3 } \\
\text { Aa2 } \\
\end{array}$ \\
\hline Italy & $\begin{array}{l}\text { Banca Intesa } \\
\text { Unicredito It. }\end{array}$ & $\begin{array}{l}22,200 \\
20,684 \\
\end{array}$ & $\begin{array}{l}374,552 \\
362,626 \\
\end{array}$ & $\begin{array}{c}\mathrm{A} 1 \\
\mathrm{Aa} 2\end{array}$ \\
\hline Belgium & KBC Group & 17,645 & 314,678 & Aa3 \\
\hline Denmark & Nordea & 17,127 & 376,629 & Aa3 \\
\hline
\end{tabular}

Source: Euromoney Magazine, July 2005.

\section{Key Liquidity Risk Management Factors}

The results of the study are based on an in-depth content analysis of the annual reports, book-year 2004, published by twenty-one of Western Europe's largest financial groups using ten key liquidity risk factors proposed by the BCBS and its Joint Forum $(2000,2003,2006)$. These key liquidity risk management factors are listed next in Table 2.

Table 2

\section{Key Liquidity Risk Management Factors (KLF)}

\begin{tabular}{|l|l|}
\hline KLF 1: & Developing a Structure for Managing Liquidity \\
\hline KLF 2: & Measuring and Monitoring Net Funding Requirements \\
\hline KLF 3: & Managing Market Access \\
\hline KLF 4: & Contingency Planning \\
\hline KLF 5: & Foreign Currency Liquidity Management \\
\hline KLF 6: & Internal Controls for Liquidity Management \\
\hline KLF 7: & Role of Public Disclosure in Improving Liquidity \\
\hline KLF 8: & Role of Supervisors \\
\hline KLF 9: & $\begin{array}{l}\text { Coverage of the Four Origins of Cash Flows: Assets, Liabilities, Off-Balance-Sheet Activities, Sources } \\
\text { and Uses of Funds, Other }\end{array}$ \\
\hline KLF 10: & Distinction Between Funding Liquidity Risk and Market Liquidity Risk \\
\hline
\end{tabular}

Each key liquidity risk management factor (KLF) will reveive a score of 1, 2 or 3 based on the extent and quality of its "Qualitative discussion" of this factor. That is, a less substantive qualitative discussion scores 1, a substantive qualitative discussion scores 2 , a more substantive qualitative discussion scores 3 which is the highest 
score. Similarly, each key liquidity risk management factor (KLF) will receive a score of 1,2 or 3 depending on the extent and quality of its "Quantitative information" supporting the "Qualitative discussion" of this factor. That is, less substantive quantitative information scores 1 , substantive quantitative information scores 2 , more substantive quantitative information scores 3 which is the highest score. It follows that each key liquidity risk management factor (KLF) can be attributed a maximum score of 6; that is, 3 for the quality and extent of the qualitative discussion and another 3 for the quality and extent of the quantitative information supporting the qualitative discussion. Il also follows that each financial group can receive a maximum score of 60 since ten KLFs are used and each can be scored a maximum of six. Once the analysis is completed and scored for all ten KLFs and all twentyone financial groups, quantitative comparisons will be made between financial groups, countries of origin, key liquidity factors, and credit ratings.

\section{THE EMPIRICAL RESULTS}

The purpose of this section is to present and more closely examine the empirical results on the informational content and the usefulness of financial groups' liquidity risk public financial disclosure. The results of the analysis will be presented in four parts each of which addressing one of the four previously formulated research questions.

\subsection{Liquidity Risk Financial Disclosure Differences Between Financial Groups}

Table 3

Key Liquidity Risk Management Factors (KLF) Scores*

\begin{tabular}{||l|c|c|c|c|c|c|c|c|c|c|c||}
\hline \hline Financial & KLF & KLF & KLF & KLF & KLF & KLF & KLF & KLF & KLF & KLF & TOTAL \\
Group & $\mathbf{1}$ & $\mathbf{2}$ & $\mathbf{3}$ & $\mathbf{4}$ & $\mathbf{5}$ & $\mathbf{6}$ & $\mathbf{7}$ & $\mathbf{8}$ & $\mathbf{9}$ & $\mathbf{1 0}$ & $\mathbf{6 0}$ \\
\hline HSBC Holdings & 3,1 & 2,1 & 2,1 & 2,1 & 2,3 & 2,1 & 3,1 & 3,1 & 3,3 & 3,2 & 40 \\
Royal Bk. Scot. & 2,1 & 2,1 & 1,1 & 2,1 & 3,3 & 1,1 & 2,2 & 3,3 & 2,3 & 3,2 & 39 \\
Barclays & 3,1 & 3,3 & 1,1 & 3,1 & 1,2 & 3,1 & 2,1 & 2,1 & 2,3 & 3,1 & 38 \\
HBOS & 2,1 & 2,2 & 2,1 & 2,1 & 2,2 & 3,1 & 2,1 & 3,1 & 2,2 & 3,2 & 37 \\
Lloyds TSB Gr. & 1,1 & 3,2 & 2,3 & 2,1 & 2,3 & 2,1 & 2,2 & 2,2 & 2,3 & 2,3 & 41 \\
\hline Groupe Cr. Agr. & 3,3 & 3,3 & 2,1 & 1,1 & 2,2 & 2,1 & 1,1 & 1,2 & 2,1 & 2,2 & 36 \\
BNP Paribas & 2,1 & 2,2 & 2,1 & 1,1 & 2,1 & 2,1 & 1,1 & 2,2 & 2,2 & 2,2 & 32 \\
Soc. Générale & 1,1 & 2,2 & 2,2 & 1,1 & 2,2 & 1,1 & 1,1 & 2,3 & 2,2 & 2,1 & 32 \\
Gr. Caisse. Ép. & 3,2 & 2,3 & 3,3 & 1,1 & 3,2 & 3,1 & 2,1 & 3,2 & 2,1 & 3,1 & 42 \\
\hline Santander & 2,2 & 3,2 & 2,1 & 3,1 & 2,3 & 1,1 & 1,1 & 1,1 & 2,2 & 2,1 & 34 \\
Banco B.V.A. & 2,1 & 2,2 & 2,1 & 2,1 & 3,3 & 1,1 & 2,1 & 1,1 & 2,2 & 2,2 & 34 \\
\hline Deutsche Bank & 3,1 & 2,1 & 1,1 & 3,3 & 2,2 & 2,1 & 1,1 & 3,1 & 2,2 & 3,2 & 37 \\
\hline Cr. Suisse Gr. & 2,1 & 1,2 & 2,1 & 2,1 & 2,2 & 1,1 & 3,1 & 2,3 & 2,2 & 2,1 & 34 \\
UBS & 1,2 & 2,2 & 1,1 & 2,1 & 2,2 & 1,1 & 2,1 & 2,3 & 3,3 & 2,1 & 35 \\
\hline Rabo Bank Ned. & 2,1 & 2,2 & 2,1 & 1,2 & 2,2 & 1,1 & 1,1 & 2,2 & 1,2 & 1,1 & 30 \\
ABN Amro Gr. & 3,2 & 1,1 & 2,1 & 2,1 & 2,2 & 1,1 & 1,1 & 2,1 & 2,2 & 1,1 & 30 \\
ING Group & 3,1 & 1,1 & 2,1 & 2,1 & 2,2 & 1,1 & 1,1 & 1,1 & 3,3 & 3,1 & 32 \\
\hline Banca Intensa & 2,1 & 2,1 & 2,1 & 2,1 & 1,1 & 2,1 & 2,2 & 1,1 & 2,2 & 2,1 & 31 \\
Unicredito It. & 3,1 & 2,2 & 3,3 & 1,1 & 2,2 & 3,1 & 1,1 & 2,1 & 2,2 & 1,1 & 35 \\
\hline KBC Group & 3,1 & 2,1 & 3,3 & 2,1 & 3,2 & 2,1 & 1,1 & 1,1 & 2,2 & 1,1 & 34 \\
\hline Nordea & 2,2 & 3,3 & 1,1 & 2,2 & 2,2 & 1,1 & 1,1 & 1,1 & 3,2 & 1,1 & 33 \\
\hline TOTAL & 76 & 83 & 70 & 64 & 89 & 57 & 57 & 74 & 91 & 74 & \\
\hline
\end{tabular}

\footnotetext{
${ }^{*}$ The first score evaluates the extent and quality of the qualitative discussion of the factor. The second score evaluates the quantitative information supporting the quantitative discussion of the same factor.
} 
As can be seen in table 3 on KLF total scores, there were marked differences between financial groups. Financial groups that made the most extensive qualitative and quantitative liquidity risk financial disclosures included: Groupe Caisse d'Épargne (42) Lloyds TSB Group (41) and HSBC Holdings (40). Conversely, the financial groups that made the least extensive qualitative and quantitative liquidity risk financial disclosures include: Rabo Bank Ned. (30), ABN AMRO Group (30) and Banca Intensa (31). Note also in Table 3 that the financial groups that made the most extensive disclosures did so across most of the $10 \mathrm{KLF}$ disclosure areas. In addition, the financial groups that made the least extensive disclosures did so across most of the 10 KLF disclosure areas. The results also show that most financial groups scored relatively higher on KLF qualitative factors as opposed to quantitative ones, this point is more clearly illustrated in table 4 which shows that average qualitative scores were higher than average quantitative scores for eight out of the ten KLF factors. In addition, the average of qualitative scores over all ten KLF factors was 1.97 over 3.0 which is substantially higher than 1.54 the average of quantitative scores over 3.0.

Table 4

Klf Average Qualitative And Quantitative Scores

\begin{tabular}{|c|c|c|c|c|c|c|c|c|c|c|c|}
\hline & $\begin{array}{l}\text { KLF } \\
1\end{array}$ & $\begin{array}{l}\text { KLF } \\
2\end{array}$ & $\begin{array}{l}\text { KLF } \\
3\end{array}$ & $\begin{array}{l}\text { KLF } \\
4 \\
\end{array}$ & $\begin{array}{l}\text { KLF } \\
5\end{array}$ & $\begin{array}{l}\text { KLF } \\
6\end{array}$ & $\begin{array}{l}\text { KLF } \\
7\end{array}$ & $\begin{array}{l}\text { KLF } \\
8\end{array}$ & $\begin{array}{l}\text { KLF } \\
9\end{array}$ & $\begin{array}{l}\text { KLF } \\
10\end{array}$ & $\begin{array}{l}\text { KLF } \\
\text { AVG }\end{array}$ \\
\hline $\begin{array}{l}\text { Total } \\
\text { Avg. }\end{array}$ & 76 & 83 & 70 & 64 & 89 & 57 & 57 & 74 & 91 & 74 & 73,5 \\
\hline $\begin{array}{l}\text { Qual. } \\
\text { Score } \\
\text { Avg. }\end{array}$ & 2,29 & 2,10 & 1,90 & 1,86 & 2,10 & 1,71 & 1,57 & 1,90 & 2,14 & 2,10 & 1,97 \\
\hline $\begin{array}{l}\text { Quant. } \\
\text { Score } \\
\text { Avg. }\end{array}$ & 1,33 & 1,86 & 1,43 & 1,19 & 2,14 & 1,00 & 1,14 & 1,67 & 2,19 & 1,43 & 1,54 \\
\hline $\begin{array}{l}\text { Total } \\
\text { Score }\end{array}$ & 3,62 & 3,95 & 3,33 & 3,05 & 4,24 & 2,71 & 2,71 & 3,57 & 4,33 & 3,52 & 3,50 \\
\hline
\end{tabular}

\subsection{Liquidity Risk Financial Disclosure Differences Between The Ten Key Liquidity Factors}

As can be seen in table 3, measuring and monitoring net funding requirements (KLF 2) and foreign currency liquidity management (KLF 5) as well as coverage of the four origins of cash flows (KLF 9) presented the most complete qualitative discussions and the most substantive quantitative illustrations. The results also show that the level and extent of financial disclosure was about average for KLF1, KLF3, KLF8 and KLF10. However, the level and extent of financial disclosure, both qualitative and quantitative, were comparatively low for the crucial areas of contingency planning (KLF 4) and internal controls for liquidity management (KLF 6). Explaining and illustrating the role of public disclosure in improving liquidity (KLF 7) and KLF 6 both received the lowest relative financial disclosure scores.

To provide more tangible explanations of what is meant by above peer group financial disclosure, a more detailed illustration is provided next using KLF 2 measuring and monitoring net funding requirements. Three financial groups, Barclays and Groupe Crédit Agricole and Nordea, each received the highest possible total score (six) since both their qualitative discussion and quantitative illustration received the highest possible score of three. For example, Barclays explains very clearly how it measures and projects cash flows on a daily basis, also weekly and monthly. Groupe Crédit Agricole explains and illustrates its cash flow modeling, as well as its use of a monthly liquidity coefficient. Finally, Nordea provides detailed explanations of its monthly funding gap measure, as well as its use of a stable net funding requirement estimation model; that is, the estimated difference between the balance of stable assets and stable liabilities. Similar illustrations could be provided here on all other KLFs; unfortunately this is not possible because of space limitation in this paper. However, all of the more detailed study results are available from the corresponding author upon request.

\subsection{Liquidity Risk Financial Disclosure Differences Between Countries}

This section presents the analysis of liquidity risk financial disclosure differences between the nine Western 
European countries included in this study. Given the heterogeneous nature of the countries of origin and their financial groups, the results on KLF average total score per country presented in table 5 can only be considered to be preliminary. Nevertheless, even preliminary results are of interest since all prior and comparable work to this study published by the BCBS and its Joint Forum on financial disclosure have never revealed before individual financial group disclosure performance or individual country disclosure performance. Given these limitations, the results indicate that the level and extent of liquidity risk management financial disclosures were above peer country average for the United Kingdom and Germany, and below average for Italy and the Netherlands.

Table 5

Klf Average Total Score Per Country

\begin{tabular}{|ccc||}
\hline $\begin{array}{c}\text { Country } \\
\text { \# Fin. Groups) }\end{array}$ & Rank & $\begin{array}{c}\text { Avg. Total Score } \\
\text { Per Country /60 }\end{array}$ \\
\hline U.K. (5) & 1 & 39 \\
Germany (1) & 2 & 37 \\
France (4) & 3 & 35,5 \\
Switzerland (2) & 4 & 34,4 \\
Spain (2) & 5 & 34 \\
Belgium (1) & 5 & 34 \\
Denmark (1) & 7 & 33 \\
Italy (2) & 8 & 32,5 \\
Netherlands (3) & 9 & 30,7 \\
All Countries (21) & - & 34,4 \\
\hline \hline
\end{tabular}

\subsection{Liquidity Risk Financial Disclosure Differences Between Credit Rating Categories}

This section presents the analysis of liquidity risk financial disclosure differences between the five credit rating categories attributed to the twenty-one large financial groups included in this study. Moody's long-term debt credit ratings were shown in Table 1 for each of twenty-one financial groups. The results presented in Table 6 on KLF average total score per credit rating category originate from the Table 1 information on credit ratings and the Table 3 information on KLF scores.

Table 6

KLF Average Total Score Per Credit Rating

\begin{tabular}{||cccccc||}
\hline Credit Rating Category & Aaa & Aa1 & Aa2 & Aa3 & A1 \\
\hline \# of Fin. Groups (21) & $2^{*}$ & 2 & 9 & 7 & 1 \\
KLF total avg. scores & 35,5 & 38,5 & 35,9 & 33,4 & 30 \\
\hline
\end{tabular}

*For example, (Lloyds TSB Gr. (41) + Rabo Bank Ned. (30)) / 2 = 35,5

Even if the results reported above in Table 6 on the level and extent of liquidity risk financial disclosures are to be considered only as preliminary, they are nevertheless quite interesting. With only one exception, in rating category Aaa, the KLF total average scores were distinctly higher (lower) in higher (lower) credit rating categories. Based on the empirical results presented so far in this study, financial groups that have earned a higher credit rating category were also the institutions that made the most complete and extensive liquidity risk financial management disclosures.

\section{DISCUSSION AND CONCLUSION}

This paper examined the informational content and the usefulness of financial groups' liquidity financial disclosure. The results of the study are based on an in-depth content analysis of the annual reports (2004) published by twenty-one of Europe's largest financial groups using the key liquidity risk management factors (KLF) proposed 
by the BCBS and its Joint Forum (2003, 2006). The results of the study revealed a wide disparity in the level and extent of liquidity risk financial disclosures between financial groups from the same or different European countries. For most of the ten KLFs, the scores obtained on the level and extent of qualitative discussions were higher than those relating to quantitative illustrations of the same KLF. The most complete qualitative discussions and the most substantive quantitative illustrations were provided for the three following KLFs: measuring and monitoring net funding requirements (KLF2) and foreign currency liquidity management (KLF 5) as well as coverage of the origins of cash flows (KL9). Conversely, the level and extent of financial disclosures were found to be the least complete and the least substantive in the following three KLFs: contingency planning (KLF 4), internal controls for liquidity management (KLF 6) and explaining and illustrating the role of public disclosure in improving liquidity (KLF 7). Finally, the results of the study showed that financial groups that have earned a relatively high (low) credit rating category were also the institutions that made the most complete and extensive, both qualitative and quantitative, liquidity risk management financial disclosures.

\section{ACKNOWLEDGEMENTS}

Financial support from the Groupe de Recherche en Capital de Risque of the Desjardins Chair in Sustainable Development is gratefully acknowledged.

This article is part of a research program receiving financial support from the Venture Capital Group of the Desjardins Chair in Sustainable Development at Université de Sherbrooke.

Data Availability: The data used in this study can be obtained from public sources.

\section{REFERENCES}

1. Basel Committee on Banking Supervision, The Joint Forum, 2006. The Management of Liquidity Risk in Financial Groups. Bank for International Settlements (May).

2. Basel Committee on Banking Supervision.2004. International Convergence of Capital Measurement and Capital Standards:a Revised Framework. No. 107 (June).

3. Basel Committee on Banking Supervision, The Joint Forum, 2004. Financial Disclosure in the Banking, Insurance and Securities Sectors: Issues and Analysis. Bank for International Settlements (May).

4. Basel Committee on Banking Supervision. 2003b. Public Disclosures by Banks: Results of the 2001 Disclosure Survey. Basel Committee Publications No. 97 (May).

5. Board of Governors of the Federal Reserve System. 2000. Improving Public Disclosure in Banking. Staff Study \# 173.

6. $\quad$ Hirst, D.E.,P.E.Hopkins,and J.M.Wahlen. 2004. Fair Values,Income Measurement,and Bank Analysts' Risk and Valuation Judgments. The Accounting Review 79, pp.453-472.

7. Hirtle,B.J. 2003. What Market Risk Capital Reporting Tells Us About Bank Risk. Economic Policy Review 9, FRBNY, (September), pp.37-54.

8. Jorion, P. 2002. How Informative Are Value-at-Risk Disclosures? The Accounting Review 77, pp. 911-931.

9. Ke, B. 2004. Discussion of How Banks' VaR Disclosures Predict their Total and Priced Risk. Review of Accounting Studies 9 (June-September), pp. 295-299.

10. Kwan, Simon H. 2002. Bank Security Prices and Market Discipline. FRBSF Economic Letter 2002-37 (December 20).

11. Kwan, Simon H. 2006. Safe and Sound Banking, 20 Years Later. FRBSF Economic letter 2006-26 (October 6).

12. Linsmeier, T., D. Thornton, M. Venkatachalam, and M. Welker. 2002. The effect of mandated market risk disclosure on trading volume sensitivity to interest rate, exchange rate, and commodity price movements. The Accounting Review 77 (April): 343-378.

13. Liu, C.C., Ryan, S.G., Tan, H. 2004. How Banks' VaR Disclosures Predict their Total and Priced Risk. Review of Accounting Studies 9 (June-September), pp. 265-294.

14. Lopez, Jose A. 2004. Supervising Interest Rate Risk Management. FRBSF Economic Letter 2004-26 (September 17).

15. Lopez, Jose A. 2003. Disclosure as a Supervisory Tool: Pillar 3 of Basel II. FRBSF Economic Letter 200322 (August 1). 
16. Préfontaine, J., Desrochers, J., Kadmiri, O. 2006a How Informative Are Banks' Earnings-at-Risk and Economic Value of Equity-at-Risk Public Disclosures? Insurance and Risk Management, vol. 74 (1), April, $1-19$.

17. Préfontaine, J., Houde, D., Desrochers, J., Martel, D. 2006b. The Informational Content of the VaR Measures Associated with the Trading Activities of Canadian Banks. IBER conference, Las Vegas Nevada, October 2006, Best paper award, to be published in 2007 in the Journal of Business and Economics Research.

18. Sierra, G. E., Yeager, T. J. 2004. What Does The Federal Reserve's Economic Value Model Tell Us About Interest Rate Risk at U.S. Community Banks? Review 86, FRBSL (Nov./Dec.), pp. 45-60.

\section{NOTES}

